\title{
Research
}

\section{Exploring Strategies that Build Livelihood Resilience: a Case from Cambodia}

\author{
$\underline{\text { Melissa J. Marschke }}^{1}$ and Fikret Berkes ${ }^{2}$
}

\begin{abstract}
Livelihoods in Cambodian fishing communities are complex and dynamic. Fluctuations in resource abundance, seasonal cycles of resource use, and changes in access create conditions that bring challenges for rural households, as do economic and policy drivers. Nonetheless, people are continuously "doing something" in response to these stresses and shocks. This paper sets out to explore how households and community members attempt to mitigate against such challenges. The analysis of livelihood stresses and shocks in two Cambodian fishing villages shows that diversification is a commonly used strategy for coping and adapting. Analyzing responses at multiple scales, with emphasis on resilience-building strategies at household and community levels, illuminates aspects of livelihoods. To study local-level perspectives of resilience, well-being was used as the surrogate of resilience, producing three clusters of responses related to economic conditions, resources, and relationships.
\end{abstract}

Key Words: Cambodia; diversification; livelihood; resilience; scale; uncertainty; well-being

\section{INTRODUCTION}

Livelihoods in many rural areas of the world are complex and dynamic: perhaps the one constant is the day-to-day uncertainty of survival. The concept of livelihood is about individuals, households, or groups making a living, attempting to meet their various consumption and economic necessities, coping with uncertainties, and responding to new opportunities (de Haan and Zoomers 2003). Some of the earlier approaches in livelihood studies regarded poor people as passive victims. However, the trend since the 1990s has been to study survival strategies. Influenced by the work of Scoones (1998), particular attention is paid to the world of lived experience, at the levels of the household, social networks, and the community (de Haan and Zoomers 2005). Such an approach to the study of livelihoods is actor oriented, place focused, and context specific (Kirkby et al. 2001). Other studies have worked from a vulnerability and social security perspective; several have focused on disturbances and local vulnerabilities (Blaikie 1995, Adger et al. 2001). Investigations into change processes and adaptation have included short-term (Davies 1996) and long-term responses (Singh and Gilman 1999).
A seminal paper by Chambers and Conway (1992:6) suggested that "a livelihood is sustainable when it can cope with and recover from stresses and shocks, maintain or enhance its capabilities, assets and entitlements, while not undermining the natural resource base." However, few livelihood studies have pursued the agenda of how livelihoods "can cope with and recover from stresses and shocks," and the resilience analysis that this would entail (Berkes et al. 2003). Stresses and shocks that impinge upon livelihoods are the result of interactions between global forces and local contexts (de Haan 2000, de Haan and Zoomers 2003, Armitage and Johnson 2006). Fluctuations in resource abundance, seasonal cycles of resource use, and changes in access create conditions that bring challenges for rural households. Similarly, economic drivers (world markets, unaffordable credit) and policy drivers (misguided government programs) also create stresses and shocks that impact rural life (International Federation of the Red Cross and Red Crescent Societies 2004, Millennium Ecosystem Assessment (MA) 2005).

According to Turner et al. (2003), a stress is a continuous or slowly increasing pressure, commonly within the range of normal variability, 
whereas a perturbation (shock) is a major spike in pressure beyond the normal range of variability in which the system operates. Stresses tend to be ongoing as in the case of resource declines; seasonality issues, such as lean times; and perturbations and fluctuations within the socialecological system. The onset of shocks tends to be intense and dramatic, such as the December 2004 tsunami that hit Asian coastal communities; economic devaluation (Thailand economic crash of 1997); or violent conflicts (Khmer Rouge, Cambodia, 1975-1979). Although stresses and shocks can fade so that life appears to return to normal, such "equilibrium thinking" (de Haan 2000:348) does not enable an understanding of how households respond, and continually adjust, to change.

The analysis can be taken further by analyzing livelihood strategies as attempts to add options, and build buffering ability to deal with perturbations. It may be instructive to examine responses in terms of building capacity to deal with future change (Folke et al. 2003); that is, to examine strategies that might foster or enhance resilience. Resilience offers a lens with which to explore stresses and shocks and to understand livelihood dynamics. Defined as "the capacity of a system to absorb disturbance and reorganize while undergoing change so as to still retain essentially the same function, structure, identity, and feedbacks" (Walker et al. 2004), resilience is future oriented, and is used to characterize a system's ability to deal with change. In resilient social-ecological systems, change and renewal may nurture novelty and innovation (Folke et al. 2002).

The objective of this paper is to use the concept of resilience as an analytical approach in furthering the understanding of livelihoods, specifically considering the dynamics of how people make a living, and the various characteristics of complex adaptive systems, in particular scale and uncertainty. We are interested in the usefulness of resilience thinking in understanding livelihood challenges and how people deal with them. Are there any strategies at the household, community, or national level that might enhance rural livelihoods? The analysis highlights those livelihood strategies that fishers consider to be critical for enhancing their wellbeing. We do not attempt here a critique of resilience thinking and its assumptions as they pertain to a social science field such as livelihoods and development. In particular, we do not address to any extent the political issue of "for what and for whom are we trying to promote resilience?" as this has been done elsewhere (Armitage and Johnson 2006). But we do acknowledge the crucial importance of contextual factors in a given case.

After an explanation of the study area and methods, we present an overview of the stresses and shocks found in the two Cambodian fishing communities. This overview includes an examination of livelihood diversification as a coping strategy and potentially an adaptive strategy. Resiliencebuilding strategies observed at various levels (in particular, the household and community levels) are then explored, with specific attention to three clusters of strategies (adapted from Folke et al. 2003, Berkes and Seixas 2005): learning to live with change and uncertainty, nurturing learning and adapting, and creating opportunities for selforganization. In the last section, notions of wellbeing are examined from a community perspective, as a way of providing a "surrogate" (Carpenter et al. 2005) for resilience.

\section{STUDY AREA AND METHODS}

Low GDP per capita (USD 270) makes Cambodia one of the poorest countries in the world (World Bank 2004). For this study, two Cambodian fishing communities - one coastal (Koh Sralao) and one lake (Kompong Phluk) (Fig. 1) -were selected to investigate rural livelihoods over a 21 -month period in 2002-2004. Both these study communities are poorer than the Cambodian average in terms of human development indicators (Human Development Report 2002) and have limited access to land. Health and educational services are minimal, with people relying on provincial centers for non-traditional health care needs. Although intra-community socioeconomic differentiation does occur, the gradient of difference is perceived by villagers themselves to be relatively narrow, which is consistent with other findings of socioeconomic differentiation in rural Cambodian communities (Legerwood and Vijghen 2002). Common-pool, resource-based activities (fisheries and forestry) are important livelihood strategies for subsistence and economic purposes (Marschke 2005).

Each site was selected because of community-based natural resource management activities in the area 
Fig. 1. The two research areas, Cambodia.

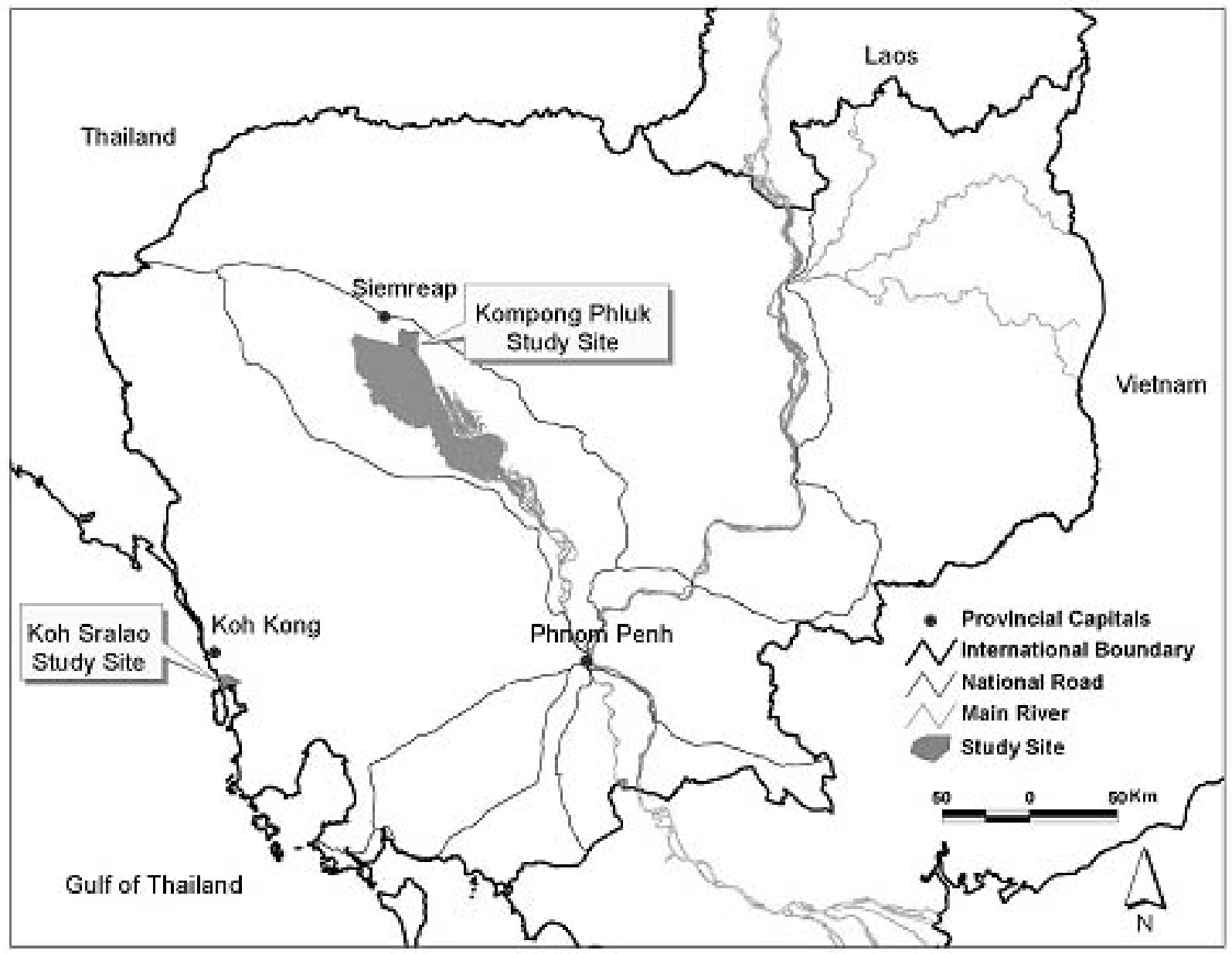

and household reliance on fish and flooded forests in pursuing livelihood strategies. Koh Sralao is a coastal fishing village with 1992 inhabitants, and consists of many internal migrants who came to pursue economic opportunities (often related to resource exploitation); Kompong Phluk is a fishing commune (consisting of three villages that are spatially connected) with 2755 inhabitants, where households move seasonally with the movements of the Tonle Sap Lake (the Tonle Sap is a floodplain lake that shrinks in the dry season and greatly expands during the rainy season). Both communities were established before the genocidal Khmer Rouge regime (1975-1979) although most households in Koh Sralao did not return after the Khmer Rouge (many households fled to Thailand or elsewhere) (Marschke 2005).

Each community is located in an ecologically significant area. Koh Sralao village is located within Peam Krasaop Wildlife Sanctuary, a protected area. This same area has also been designated as a Ramsar site, one of three in Cambodia. Kompong Phluk is located within a Biosphere Reserve. Both communities existed before outside recognition of the ecological significance of their environments. Perhaps as a result of the donor emphasis on decentralization processes, including local-level 
resource management (see Blunt and Turner 2005, Ratner 2006), and the ecology found in Koh Sralao and Kompong Phluk, there were opportunities for villagers to gain support for dealing with resource governance issues. As such, active local-level resource management committees are found in both Koh Sralao and Kompong Phluk (details on this aspect are given in Marschke and Berkes (2005)).

Qualitative and quantitative methods were used for data collection and analysis, spanning the household, community, and provincial/national levels. Participatory research methods (Ellis 2000, Chambers 2004) included (a) four community workshops focusing on livelihood and resilience, (b) focus-group sessions with households and two resource-management committees followed over the long term, and (c) quantitative methods included a livelihood survey representing $20 \%$ of the households in each community $(n=148)$. For household-level discussions, we were particularly interested in how households (and individuals within households) dealt with change over time. Research findings were supplemented with the use of other participatory methods and discussions with officials at various levels. The use of computer software, NVivo and SPSS, supported qualitative and quantitative analysis. Research findings were shared with community members and government agencies through project reports and dissemination workshops, both for verification and for continuing the research dialogue. These three major approaches provide a triangulation. For more details related to research methods, see Marschke (2005).

\section{RESULTS AND DISCUSSION}

\section{Dealing with Stresses and Shocks: the Reality of Daily Life}

Living is not easy; life is complicated. A tree is growing, and gets a little stronger. Then a branch gets cut, and it is hard to climb any higher.-Sok, pers. comm., May 2003.

Sok's insights hint at the constant challenge households face in daily life. By saying "gets a little stronger....then....gets cut," Sok is speaking about how just as one challenge is resolved, another may be revealed. Perhaps in English the expression "one step forward, two steps back" also hints at the frustration of dealing with challenges. Sok used this metaphor of "being hard to climb a tree as branches are being cut" during one visit when we discussed the implications illness might have for his household.

In the context of Koh Sralao and Kompong Phluk, both stresses (within normal variability) and shocks (major spike beyond normal variability) occur. The line between stresses and shocks may be blurred, representing a continuum of adverse conditions that people deal with. The distinction between stress or shock is not always clear; what may be a stress for one household may be a shock for another. Moreover, a shock at one scale may be a stress at another scale, or vice versa. Nonetheless, Table 1 highlights our best reading of stresses and shocks faced in the communities of Koh Sralao and Kompong Phluk.

Reduced access to commons and a declining resource base are ongoing stresses for resourcedependent fishing communities. For example, in early 2005, fishers in Koh Sralao noted that they no longer caught grouper juveniles as a by-catch in their crab traps, and another income source vanished. The 2003-2004 fish catch was the lowest ever recorded in the Tonle Sap (Hortle et al. 2004). Seasonal perturbations (lower water levels in the Tonle Sap, increased rains in the coastal area and storms in both cases), challenges in accessing capital to secure additional livelihood options, and chronic poor health are other ongoing stresses that many households face.

There is an ever-increasing fishing pressure along the Tonle Sap Lake and in coastal areas: more fishers are competing over declining resources in the same fishing grounds. Conflict ensues, manifested in gear loss. Trawlers and other boats operating larger-scale gears often destroy gill nets and traps when accessing the same fishing grounds as smaller-scale fishers. Even more problematic is the persistence of fishing gear theft (fish traps and sections of gill nets) in each area. Gear loss illustrates how something that may be a shock at one level is a stress at another level. For example, the theft of a fishing net is probably an episodic shock to a household, whereas the increasing incidence of net theft is a stress at the community level that results in loss of trust and in inter-community strife.

Shocks, such as forest fires or market closures, can have intense ramifications for a household or a community. In July 2003 a 62-ha forest fire broke 
Table 1. Stresses and shocks found in the two fishing communities. The items at the top of the table are predominantly stresses, integrating into items at the bottom of the table that are predominantly shocks.

Item

Reduced access to common fishing grounds

Declining resources (fish and forest)

Loss of fishing gear

Being at the mercy of markets

Chronic poor health

Threat of violence during elections

Forest fire in flooded forest: July 2003, Kompong Phluk

Thai border closing: Jan 2003, Koh Sralao

Charcoal ban: 1999, Koh Sralao

Khmer Rouge, 1975-1979
Explanation, including observed response (if any) to stress or shock

With decreasing access to fishing grounds, conflicts have arisen in the past decade. Fishers protested, and in 2001, areas in the Tonle Sap were designated for community fisheries management. At the same time, a community fisheries unit was created in the Department of Fisheries. Decentralization programs, community-based management initiatives, and new legislation are policy responses meant to support the "local."

Progressive decline in wildlife and fish populations, along with habitat degradation. Overharvesting, inappropriate "quick-catch" fishing gear. Limited enforcement of existing laws.

Stolen or destroyed fishing gear (traps and gill nets) presents a challenge for households (i.e., to pay off debt). Fisheries organizations grapple with this issue. Local authorities (police, commune council, technical staff) are hesitant to take this on.

Market demands and fluctuating commodity prices; boom-bust marketing cycles. No one to buy a product (sell-while-you-can mentality). Fishers rely on layers of middlepersons to sell resources.

A challenge if a main household income generator has "little energy." In 2002, nearly all households claimed that someone within their household was ill.

Especially for those households that are politically engaged. Belonging to the opposition party may result in social exclusion, sometimes forcing households to switch their allegiances. General nervousness during any election period (uncertainty).

62 ha burned near Kompong Phluk; took 1 week to douse. Elders directed the situation. Triggered an active fire prevention campaign.

Limited supplies in Koh Sralao for 1 month; fish products fetched $1 \frac{1}{2}$ the normal market value and gasoline prices rose.

Forced more people into crab fishing or to leave the area. This shifted pressure from one resource (mangrove degradation for charcoal) to another (the fishery).

Left a generation suffering from post-traumatic stress disorder. Trust within communities may be limited. 
out near Kompong Phluk in a "protection forest" area, a dense forest patch that helped to protect houses from wind and storms. The entire community prepared to evacuate, although the fire was put out after a week of fire fighting (a provincial fire truck came within a few days to help douse the fire). Many animals were killed and resources (such as water snakes) were lost. The fire exacerbated the long-standing tension between residents and seasonal fishers who access local fishing grounds.

Life for rural Cambodian fishers is unquestionably filled with uncertainty and challenges. In the absence of basic services and social safety nets, communities are faced with real dilemmas in finding solutions to their challenges. Although a political analysis is beyond the scope of this paper (but see Marschke and Berkes 2005, Marschke 2005), there are serious structural barriers that prevent households from attaining their livelihood goals. Yet further analysis in Koh Sralao and Kompong Phluk suggests that fishers and locallevel institutions are willing to take some risks to try some innovative solutions. How, then, might households and local-level institutions deal with ongoing stresses and shocks?

\section{Diversification and its Nuances}

It is better that we do more than fish in my household. My one daughter cuts clothes, and my wife sells goods from our home. My other daughter helps with fishing and marketing our fish products. Since there are not so many fish this year and we catch less fish during this season, I sent my two sons to the city to try to find other work. If they find work, this could help our future. For now, I continue fishing.--Norn, pers. comm., November 2003.

In Norn's case, diversification of this household's livelihood activities is a strategy that is both reactive and opportunistic. Seasonal perturbations are part of the fishery, hence Norn continues to fish as the household's main livelihood activity while his sons pursue potential non-fishing activities. As Norn's comments illustrate, livelihood strategies are the product of the interaction between choice and constraint (Start and Johnson 2004). Norn's choice to diversify is an example of a coping strategy to deal with fewer resources, and (potentially) an opportunity if his sons can access growing economic opportunities in the provincial capital. Diversification is part of household life in Koh Sralao and Kompong Phluk (Marschke 2005).
One way that diversification occurs is by putting time and effort into a series of unrelated livelihood activities, as a way of reducing overall risk (Allison and Ellis 2001, Turner et al. 2003). The few sentences from Norn illustrate this approach. Another way of achieving diversification is to build on existing livelihood activities. In Kompong Phluk, for example, diversification appears to be linked directly to the fishery, building on the complementarity of fishing-related activities. Fish processing complements home-based, part-time, domestic chores; catching fish complements processing and trade.

There are reasons for choosing diversification as a livelihood strategy. For example, for the few wellto-do fishing households in Koh Sralao and in Kompong Phluk, diversification is a strategy of wealth accumulation, whereas for the poorest fishing households, diversification may be a survival strategy, given the context of declining resources and declining access to resources. This finding is consistent with Reardon et al. (2001) who argue that it is important to understand the synergies among assets, as well as the synergies among different families' livelihoods; and to recognize that these synergies occur at a point in time, but also across time. There are structural barriers (such as the role of hierarchy and patron-client relationships in mitigating livelihood opportunities that we did not touch upon within this article) that may prevent households from diversifying their livelihoods in a meaningful manner.

Livelihood diversification may be an important angle of poverty reduction (Ellis 2000), a strategy for risk mitigation (Turner et al. 2003), or a coping or survival strategy (Reardon et al. 2001). Diversification provides one example of a household strategy for coping and potentially thriving: within both Koh Sralao and Kompong Phluk, a series of livelihood strategies can be found. The next section examines some of these livelihood strategies, which are analyzed in terms of potential resilience-building strategies.

\section{Building Livelihood Resilience: a Multi-scale Examination}

Change in the form of renewal and reorganization is an important aspect in dealing with the sustainability of social-ecological systems (Folke et al. 2002). Resilient communities can handle surprises (Levin 1999), are able to learn from 
disturbance and stress, and find opportunities for renewal. It may be useful, therefore, to consider various livelihood strategies as attempts to deal with some perturbations. Although some livelihood strategies may be considered short-term coping mechanisms, other strategies may in fact lead to enhanced options or other forward-looking strategies that help a household or community survive in the face of unpredictable changes. This raises the question of whether resilience can be enhanced or built toward producing more robust livelihood strategies.

Table 2 compiles observed responses to what can be called "building livelihood resilience." This analysis is based on the cluster of resilience factors framework of Folke et al. (2003). The categories used in Table 2 collapse the two middle categories of the four in Folke et al. (2003). There are a number of items or sub-categories, with specific examples from the two study communities. The important point in our analysis is that the various ways in which resilience can be built are not confined to any one level of organization. Hence, Table 2 analyzes responses at three levels: the household, the community, and the nation. The first category of responses has to do with learning to live with change and uncertainty. This is the cluster that includes the diversification strategy identified here in its broader conceptualization: building a portfolio of livelihood activities. The second category of responses has to do with nurturing the processes of learning and adapting. This is the cluster that includes nurturing a diversity of institutions and creating the political space for experimentation (Dietz et al. 2003). The third category of responses has to do with creating opportunity for self-organization.

The first cluster of responses in Table 2 focus on learning to live with change and uncertainty. Included in this cluster are: learning from crisis, building rapid feedback capacity, building a portfolio of livelihood options, and developing coping strategies. In both Koh Sralao and Kompong Phluk, change and uncertainty are created by biophysical changes as well as by the sociopolitical environment, and characterized by varying government policies (influenced by donor agencies and a national agenda), ever-shifting market opportunities, and continuous resource degradation. Less well-understood are the long-term effects of the Khmer Rouge genocide, in terms of its impact on nurturing trust at local and other levels.
Household and community responses in the face of change and uncertainty provide examples of learning and adapting. For instance, intense mangrove degradation in Koh Sralao forced villagers to consider a conservation ethic and to rethink their strategies for resource extraction and management. In Kompong Phluk, households seek ways of receiving rapid environmental feedback by moving with the seasonally changing water levels (and coastline) of the Tonle Sap. Most households relocate seasonally, or for part of the season, to be close to the water to monitor the weather, keep an eye on their gear, scan the environment, and share information. On the coast, Koh Sralao fishers who speak Thai monitor the weather by listening to Thai coastal radio reports; those who do not speak Thai appear to rely on word of mouth and personal observations of the weather and sea conditions.

Building a portfolio of livelihood options is seen in Kompong Phluk, in the use of social networks and reciprocal labor exchange. Dried fish is not only kept for household consumption, it is also bartered for rice. Diversifying household livelihood activities includes diversifying fishing activities (with specialization by individual family members) and non-fishing activities (e.g., operating small businesses from the home is popular in Koh Sralao). In periods of resource decline, for example, fishing households might send one income generator to the city to try and secure an alternative income source (different intra-household decision-making arrangements regarding migration do exist: it may be that household members agree to send a household member or it may be that one household member decides to leave the fishing village).

Diversification is also an example of a coping strategy. Another coping strategy to deal with change and uncertainty is to leave the village for strategic periods of time, or permanently. For example, fishers may find that the way to enhance their livelihood and well-being is out-migration. In other cases, households may be able to benefit from their proximity to other sources of growth and opportunity, provided they have the capacity to do so (Bird and Shepherd 2003). A third coping strategy is to resort to moneylenders. Coping strategies that are pursued because of a lack of alternatives (i.e., desperation strategies) tend to be very costly. Such strategies often involve running down productive assets, create unsustainability, and leave people poorer and more vulnerable than they were before (Start and Johnson 2004). Coping 
Table 2. Observed resilience-building strategies in Koh Sralao and in Kompong Phluk

\begin{tabular}{|c|c|c|c|c|c|}
\hline & \multirow{2}{*}{$\begin{array}{l}\text { Observed resilience-building } \\
\text { strategy }\end{array}$} & \multirow{2}{*}{$\begin{array}{l}\text { Observed examples for each } \\
\text { strategy in Koh Sralao (KS) and in } \\
\text { Kompong Phluk (KP) }\end{array}$} & \multicolumn{3}{|c|}{ Scale $^{1}$} \\
\hline & & & HH & $\begin{array}{l}\text { Villa- } \\
\text { ge }\end{array}$ & $\begin{array}{l}\text { Natio- } \\
\text { nal }\end{array}$ \\
\hline \multirow[t]{12}{*}{$\begin{array}{l}\text { Learning to live with } \\
\text { change and uncertainty }\end{array}$} & Learning from crisis & $\begin{array}{l}\text { Mangrove depletion encouraged } \\
\text { conservation KS }\end{array}$ & $\mathrm{X}$ & $\mathrm{XX}$ & $\mathrm{X}$ \\
\hline & & $\begin{array}{l}\text { Fishery decline led to rethinking } \\
\text { local actions KS/KP }\end{array}$ & $X$ & $\mathrm{XX}$ & $X$ \\
\hline & Building rapid feedback capacity & $\begin{array}{l}\text { Moving seasonally with changes in } \\
\text { water levels KP }\end{array}$ & $\mathrm{XX}$ & $\mathrm{X}$ & - \\
\hline & & Monitoring weather KP & $\mathrm{XX}$ & - & - \\
\hline & & $\begin{array}{l}\text { Monitoring general environment KS/ } \\
\mathrm{KP}\end{array}$ & $\mathrm{X}$ & $\mathrm{XX}$ & - \\
\hline & $\begin{array}{l}\text { Building a portfolio of livelihood } \\
\text { options }\end{array}$ & Back-up gear KP & $\mathrm{XX}$ & - & - \\
\hline & & Using social networks KP & $\mathrm{XX}$ & $\mathrm{X}$ & - \\
\hline & & Exchange labor KP & $\mathrm{XX}$ & - & - \\
\hline & & $\begin{array}{l}\text { Diversification into non-fishing } \\
\text { activities KS }\end{array}$ & $\mathrm{XX}$ & $\mathrm{X}$ & - \\
\hline & Developing coping strategies & Mobility KS & $\mathrm{XX}$ & - & - \\
\hline & & Money lenders KP/KS & $\mathrm{XX}$ & - & - \\
\hline & & Dried fish KP & $X$ & - & - \\
\hline $\begin{array}{l}\text { Nurturing learning and } \\
\text { adapting }\end{array}$ & $\begin{array}{l}\text { Nurturing ecological memory as } \\
\text { a source of innovation and } \\
\text { novelty }\end{array}$ & $\begin{array}{l}\text { Protecting forests near community } \\
\text { KS/KP }\end{array}$ & $X$ & $\mathrm{XX}$ & $X$ \\
\hline
\end{tabular}


Nurturing social memory as a source of innovation and novelty
Growing fingerlings for aquaculture $\mathrm{XX}-$ KP

Creating fish sanctuary $\mathrm{KS} / \mathrm{KP}$
Nurturing a diversity of institutions to respond to changing environment

Creating political space for experimentation

Creating opportunity for self-organization
Building capacity for user selforganization

Building conflict management mechanisms

Self-organizing in response to external drivers
How people have adapted to "Dragon X - $\mathrm{X}$

Floods" that occur approximately every 12 years KP

Recalling impact of fewer trees KS X $\quad \mathrm{XX} \quad-$

Local resource management committees $\mathrm{KS} / \mathrm{KP}$

$\mathrm{X} \quad \mathrm{XX}-$

Involving commune councils in $\quad-\quad \mathrm{X} \quad \mathrm{XX}$ resource management work KS/KP

Decentralization mandate supports $\quad-\quad-\quad \mathrm{XX}$ local initiatives $\mathrm{KS} / \mathrm{KP}$

Inputting into 2005 "Community $\quad$ - X X XX Fisheries Sub-decree” KS/KP

NGOs working with communities _ $\quad$ X $\mathrm{XX}$ $\mathrm{KS} / \mathrm{KP}$

Solving gear theft KS

$-\quad \mathrm{XX}-$

Patrolling for illegal activities KS/KP - X X

Taking advantage of market opportunities KS/KP

${ }^{1} \mathrm{HH}=$ Household, $\mathrm{X}=$ observed, $\mathrm{XX}=$ strongly observed, $-=$ not applicable

strategies may force people to make decisions favoring security and short-term gains, yet limiting potential future options (Wood 2003). Coping strategies, therefore, can have negative or positive effects on resilience.

Perhaps different configurations of livelihoods can be thought of as alternative states (Gunderson and Holling 2002). Within a given state, there can be a set of resilience-building strategies (such as those in Table 2) to maintain a given household within that state. However, that state may be characterized by poverty and coping strategies that perpetuate poverty. Such poverty traps (Barrett and Swallow 
2006) can be very resilient. Our emphasis is not on maintaining "bad" resilience but rather on building options and flexibility that improve livelihoods. Building such "good" resilience often requires learning and adaptation.

The second cluster of responses in Table 2 has to do with nurturing learning and adapting. Change and disturbance can foster learning opportunities (Levin 1999). For example, new adaptive strategies such as habitat protection for key resources are part of such learning, and both communities have experimented with locally established fish sanctuaries. Building social-ecological system memory is another way to foster learning opportunities. This includes nurturing ecological memory; e.g., using local knowledge to protect fisheries habitat and continuing with forestmonitoring systems in the case of Kompong Phluk. An example of nurturing social memory is keeping a recollection of higher-than-average annual floods at Tonle Sap, locally called "Dragon Floods," which may occur once every 12 years or so. Social memory of Dragon Floods helps the community to be prepared for unusual highs in water levels, and to know how to respond to them by building stilt houses high enough.

Nurturing a diversity of institutions to learn to deal with change is another critical resilience-building strategy. Local-level resource management institutions, supported by non-governmental organizations (NGOs) working in each area since the late 1990s, have helped create opportunities for households and villagers to solve resource management issues. The donor-driven decentralization mandate is encouraged by the way the national government has helped create the political space for local-level experimentation. For instance, the commune council, as of 2002, was mandated a role in resource management. In both Koh Sralao and Kompong Phluk, this institution (commune councils belong to a higher administrative unit than the resource management committees) supports the work of local resource management committees. Local-level work, through provincial-level connections and NGO support, has pushed for "legal" rights for community fisheries management, in the form of making inputs to the national 2005 "Community Fisheries Sub-decree."

The degree of fishers' input and influence into national policy debates and the effectiveness of such a policy in securing "rights" have yet to be analyzed.
As the commune council-local resource management committee example above illustrates, the sharing of management authority requires new linkages and multiple interactions (between villages, between villages and the $\mathrm{NGO}$, etc.), and not merely decentralization in the sense of simply passing the authority down to the local level (Adger et al. 2005).

The third cluster of responses discussed in Table 2 has to do with creating opportunity for selforganization. A resilience approach recognizes that local social systems can and do self-organize (Berkes et al. 2003), and that resilient systems require tight feedback loops in response to change, to ensure the ability to monitor and perceive an emerging problem in a timely way (Levin 1999). Elders in Kompong Phluk organized a rapid response for the entire community in the 2003 fire. Members from Koh Sralao's resource management committee stopped local fishers from destroying confiscated fishing gear, and instead encouraged non-violent conflict-resolution strategies, such as negotiation and paint-marking crab traps to discourage gear theft.

As Table 2 illustrates, resilience at a given level is not always "positive" when viewed from another level. External drivers, especially in relation to marketing opportunities, may enhance the incomegenerating ability of a household while rapidly degrading the regional ecological system and community resilience as a whole. Thus, a multiscale analysis is critical to any livelihood analysis. Such an analysis can help to capture the dynamics of livelihoods at multiple scales (Barrett and Swallow 2006). A resilience analysis with attention to scale is a potentially useful tool for development policy and resource management, as it can bring attention to unanticipated impacts at one level of intervention at another level.

For example, the protection of certain resources in community-based management policies may lead to a backlash from poorer households who earn their livelihood from these resources. There have been examples of this in the two Cambodian villages, as well as elsewhere, showing that middle-income households are often the ones that can "afford" conservation, whereas the poorest households cannot (Berkes et al. 1998). Conservation policies need to go hand-in-hand with livelihood enhancement policies at the community level, yet meet the needs of the poorer members at the household level. Corruption provides another 
example. Fishers may be patrolling their fishing areas to enforce conservation locally (Marschke and Berkes 2005). But in the meantime, their efforts may be nullified by corrupt officials making deals with large-scale fishers to exploit the whole fishing area.

\section{Well-being: Local Perspectives of Resilience}

The idea that all human societies share characteristics and capacities in common is well founded, but it is difficult to operationalize such notions (Gough 2004). The idea of well-being may be used in a universalist manner; the UN Millennium Development Goals are an example of a universialist understanding of people's capabilities and needs. Or it can be used at a local level, as in cases for "localism," in respecting people's values and knowledge, the "understanding of understandings" (Gough 2004:290). Recent work has attempted to bridge the universal and the local aspects of wellbeing, as was done in the Millennium Ecosystem Assessment (MA 2005) and in the "Voices of the Poor" study, which considered the well-being of poor people in 23 countries by giving voice to their changing realities, ideas of a "good life" and a "bad life," and aspirations (Narayan et al. 2000).

Although well-being is a descriptive term that does not get at the underlying assumptions about the feasibility of achieving a desired outcome (Start and Johnson 2004), the concept of well-being is understood by rural people in many parts of the world (Chambers 2004). Well-being as a descriptive term enables interpreters to give their own meaning to the idea of a "good life," and gives space for multiple dimensions (Chambers 2004). Notions surrounding well-being, therefore, may offer a culturally appropriate surrogate for resilience (Carpenter et al. 2005) for Cambodian rural livelihoods from a local perspective. The question is significant because what resilience may look like at the level of the household or a village has not been explored to any extent in rural Cambodia, or elsewhere.

Rather than analyze a community's or household's resilience from an outsider's perspective, we wanted to explore how community members viewed their own resilience. As we could not ask the question of resilience directly (there is no word for this concept in the Khmer language), we asked what constituted well-being (well-being translates into $s u$ ku mar peap) in relation to their livelihood, and then analyzed the responses to understand local notions of resilience. Building upon the approach of Narayan et al. (2000), several representative (gender, socioeconomic group, religious) focus groups (community level) were asked what contributed to their livelihood well-being. Table 3 is a synthesis of focus-group findings; the results are qualitative and not necessarily in order of importance. The table clusters responses into three categories: economics related; resource related; and knowledge and relationship related. The responses in the first two categories represent a consensus of the participants. Responses in the third category are not a consensus, but a compendium of selected comments, because learning and knowledge are difficult concepts to verbalize and only a few of the respondents could formulate an answer.

Villagers emphasized that one indicator of wellbeing is the ability of household members to access and use diverse types of fishing gear, ensuring flexibility to switch fishing gear depending upon season and resource abundance. Although a livelihood is definitely enhanced by having money and having diverse income-generating choices, households did not limit notions of well-being to economic opportunities. The value of local resources for livelihood and future generations was also considered important (Table 3). Pride in replanting mangroves near Koh Sralao and in sustaining an abundant flooded forest in Kompong Phluk was evident. Several villagers also hinted at the spiritual significance of having natural resources close by.

Table 3 also shows that both problem-solving skills and relationships are important aspects of wellbeing. "If you are popular with others, this will help your livelihood since you will feel good," comments Wayne (pers. com., October 2003). This suggests that a household's relationships with others can influence how they feel. Villagers also emphasized the need to take advantage of opportunities, and what was explained as "luck" (a concept that Buddhism, the dominant religion practiced in both communities, emphasizes). "Luck helps. Sometimes a rich and a poor fisher both put their nets into the water, but only one will find fish. This is based on luck" (Niet, pers. com., September 2002).

What is clear, from the villagers' perspective, is that a combination of livelihood skills and a household's adaptability contribute immensely toward successful well-being. Livelihood skills include diversity and 
Table 3. Local aspects of resilience

\author{
What contributes to your well-being? \\ ECONOMICS RELATED \\ Access to fishing gear (traps, nets) \\ Skills for multiple types of fishing \\ Other livelihood skills (animal raising, fixing, sewing) \\ Have capital and/or a supporter (neak thom) \\ Knowing how to save money \\ RESOURCE RELATED \\ Abundant trees and fish \\ Community can sustain its resources \\ KNOWLEDGE \& RELATIONSHIP RELATED \\ Knowledge and wisdom \\ Good relationships/can communicate \\ Luck \\ Can adapt and solve problems \\ Willing to struggle and make an effort
}

the economic means for experimentation, and a household's adaptability includes elements of knowledge, building good relationships and having problem-solving skills. Luck is another aspect of well-being. This combination of skills and adaptability, coupled with access to natural resources, is an important component of being resilient.

\section{CONCLUSION}

Resilience analysis illuminates the dynamics of livelihoods, highlighting the importance of scale and uncertainty. Here, we focus on adaptive responses to shocks and stresses. Elsewhere, researchers have emphasized the impact of the speed of change as a factor of resilience loss (Berkes et al. 2006), and the identification of key fast and slow variables as drivers of change and their interactions (Armitage and Johnson 2006). Our approach is consistent with these analyses in noting the importance of cross-scale interactions and of resilience building at multiple scales. As both the shocks and stresses (Table 2) and the well-being analysis (Table 3) show, household-level adaptations need to respond to a diversity of variables originating at higher political levels.

Hence, strategies to build resilience involve not only the household level but several levels of organization; they attempt to address socialecological uncertainty, including both environmental variability and economic-political drivers. Findings from the study indicate that there is always a great deal of experimentation with livelihood strategies, when possible in the direction of increasing options and flexibility - what one might call resilience building. Much of this increase in options and flexibility is reflected in diversification, which some argue is the universal strategy for risk mitigation (Turner et al. 2003). Others argue that diversification is merely the outcome of coping or survival strategies (Reardon et al. 2001, Wood 2003). There is no doubt that multiple motives prompt people to diversify their assets, incomes, and activities, as also observed by de Haan and Zoomers (2003). 
Perhaps what is most critical is the ability to diversify in a way that builds the capacity of a household livelihood to be flexible-a resiliencebuilding measure. A more resilient system implies more flexibility, but resilient systems are also defined as those able to maintain their integrity and reorganize while undergoing change (Holling 1973, Redman and Kinzig 2003, Walker et al. 2004). Hence, the definition of resilience itself provides a way of assessing if the ability to diversify is meaningful: does it contribute to increase options and flexibility, to maintain system integrity, and to renew and reorganize through processes of change? What are the limits to the ability to renew and reorganize? Can thresholds of change be anticipated?

People cannot adapt to all stresses and shocks, given the constant change communities do face. Virtually any community will face a series of challenges, such as an influx of transients, natural resource declines, infrastructure development, and protection of strategic interests (Gardner et al. 2002). In Koh Sralao and Kompong Phluk, stresses include resource depletion, fisheries conflicts (often access related, which manifested itself in gear loss, e.g., destroyed or stolen gear) and policy shifts. Illegal resource extraction by politically powerful people continues (Marschke and Berkes 2005). Nonetheless, people are continuously "doing something" in response to ongoing challenges. Households in Kompong Phluk owned back-up fishing gear and used exchange labor in lean times. Households in Koh Sralao considered diversification into nonfishing activities and sending household members elsewhere for wage labor. In both areas, villagelevel institutions were taking advantage of newly created polices that supported community-based management initiatives.

Households and village-level institutions display an ability to persist through change and learn from challenges. Some of the strategies to respond to stresses and shocks tend to be both proactive and reactive, as in mangrove replanting or sending household members in search of other livelihood activities outside the village. Table 2 shows a number of other examples in which people have been rethinking local management actions with respect to resource declines. Note that some of these responses occur at multiple levels, including environmental monitoring, forest protection, and creating community-based management committees.
The concept of well-being may be a potentially useful way to operationalize resilience on the ground. The notion of well-being, as elucidated by the two communities, includes many elements that can be interpreted as resilience building, such as learning from crises, building a portfolio of livelihood options, use of social memory, and building capacity for self-organization. An analysis of well-being complements the resilience analysis, illuminating local-level livelihood realities, and helping identify additional variables, such as relationships and luck.

Findings from this work illustrate that Cambodian fishing communities have porous, ever-shifting boundaries. They are in constant flux, involving perturbations and shifts of people and resources. However, as currently designed, resource management and development policy in Cambodia fails to take into account seasonal fluctuations, diversity of livelihood activities, and opportunities. For example, small-scale enterprise development is not seen to be a viable fit with community fisheries policy (as analyzed in Marschke 2005), even though our results indicate that those are exactly the kinds of activities that need to be combined to enable people to make a livelihood.

Perhaps local development is best understood by paying more attention to the way that households themselves respond and deal with continuous change (de Haan and Zoomers 2005). Rural livelihoods are impacted by many external drivers originating at different levels; hence, a multi-level analysis provides a fuller understanding of the livelihood system. In our Cambodian cases, the concept of resilience has been particularly useful in studying livelihood dynamics with regard to scale and uncertainty. However, resilience analysis needs to be cognizant of the historical and political context of a given system. Given that there are alternative policy options and competing interests in any given case, the question of resilience for whom and for what is ever present (Armitage and Johnson 2006). Hence, the tools of resilience are not value neutral, as in the example of community conservation strategies disproportionately impacting the poorer households. 
Responses to this article can be read online at:

http://www.ecologyandsociety.org/voll1/iss1/art42/responses/

\section{Acknowledgments:}

We would like to thank Kim Nong and Dyna Eam for their tremendous insights and support in conducting this research, along with the households and resource management committees of Koh Sralao and Kompong Phluk. We also thank two anonymous reviewers for their helpful comments. Marschke's research was supported by the International Development Research Centre (IDRC) and the Social Sciences and Humanities Research Council of Canada (SSHRC). Berkes' work was supported by the SSHRC and the Canada Research Chairs program (www.chairs.gc.ca).

\section{LITERATURE CITED}

Adger, W. N., T. Hughes, C. Folke, S. Carpenter, and J. Rockstrom. 2005. Social-ecological resilience to coastal disasters. Science 309:10361039.

Adger, W. N., P. M. Kelly, and N. H. Ninh, editors. 2001. Living with environmental change: social vulnerability, adaptation and resilience in Vietnam. Routledge, London, UK.

Allison, E. H., and F. Ellis. 2001. The livelihoods approach and management of small-scale fisheries. Marine Policy 25:377-388.

Armitage, D., and D. Johnson. 2006. Can resilience be recognized with globalization and increasingly complex resource degradation in Asian coastal regions? Ecology and Society 11(1):2. [online] URL: http://www.ecologyandsociety.org/voll1/ iss1/art2/.

Barrett, C., and B. Swallow. 2006. Fractal poverty traps. World Development 34(1):1-15.

Berkes, F., J. Colding, and C. Folke, editors. 2003. Navigating social-ecological systems: building resilience for complexity and change. Cambridge University Press, Cambridge, UK.
Berkes, F., I. Davidson-Hunt, and K. DavidsonHunt. 1998. Diversity of common property and resource use and diversity of social interests in the western Indian Himalaya. Mountain Research and Development 18:19-33.

Berkes, F., T. P. Hughes, R. S. Steneck, J. A. Wilson, D. R. Bellwood, B. Crona, C. Folke, L. H. Gunderson, H. M. Leslie, J. Norberg, M. Nyström, P. Olsson, H. Österblom, M. Scheffer, and B. Worm. 2006. Globalization, roving bandits and marine resources. Science 311:1557-1558.

Berkes, F., and C. S. Seixas. 2005. Building resilience in lagoon social-ecological systems: a local-level perspective. Ecosystems 8:967-974.

Bird, K., and A. Shepard. 2003. Livelihoods and chronic poverty in semi-arid Zimbabwe. World Development 31(3):591-610.

Blaikie, P. 1995. Understanding environmental issues. Pages 1-30 in S. Morse and M. Stocking, editors. People and the environment. UCLA Press, London, UK.

Blunt, P., and M. Turner. 2005. Decentralisation, democracy and development in a post-conflict society: commune councils in Cambodia. Public Administration and Development 25:75-87.

Carpenter, S. R., F. Westley, and M. Turner. 2005. Surrogates for resilience of social-ecological systems. Ecosystems 8:941-944.

Chambers, R. 2004. Ideas for development: reflecting forwards. IDS Working Paper 238, Institute of Development Studies, Brighton, Sussex, UK. Available online at: http://www.ids.ac.uk/ids/

Chambers, R., and G. Conway. 1992. Sustainable rural livelihoods: practical concepts for the $21^{\text {st }}$ century. IDS Discussion Paper 296, Institute of Development Studies, Brighton, Sussex, UK.

Davies, S. 1996. Adaptable livelihoods: coping with food insecurity in the Malian Sahel. Science, Technology and Development 14(1):144-156.

de Haan, L. 2000. Globalization, localization and sustainable livelihood. Sociologia Ruralis $\mathbf{4 0}$ (3):339-365. 
de Haan, L., and A. Zoomers. 2003. Development geography at the crossroads of livelihood and globalisation. Tijdschrift voor Economische en Sociale Geografie 94(3):350-362.

de Haan, L., and A. Zoomers. 2005. Exploring the frontier of livelihoods research. Development and Change 36(1):27-47.

Dietz, T., E. Ostrom, and P. C. Stern. 2003. The struggle to govern the commons. Science 302:19071912.

Ellis, F. 2000. Rural livelihoods and diversity in developing countries. Oxford University Press, Oxford, UK.

Folke, C., S. Carpenter, S. T. Elmqvist, L. Gunderson, C. S. Holling, B. Walker, J. Bengtsson, F. Berkes, J. Colding, K. Danell, M. Falkenmark, L. Gordon, R. Kasperson, N. Kautsky, A. Kinzig, S. Levin, K. Mäler, K. Moberg, L. Ohlsson, P. Olsson, E. Ostrom, W. Reid, J. Rockström, J. Savenije, and U. Svedin. 2002. Resilience for sustainable development: building adaptive capacity in a world of transformations. Rainbow series 3. International Council for Scientific Unions (ICSU), Paris, France. Available online at: http://www.sou.gov.se/mvb/pdf/ resiliens.pdf.

Folke, C., J. Colding, and F. Berkes. 2003. Synthesis: building resilience and adaptive capacity in social-ecological systems. Pages 352-387 in F. Berkes, J. Colding, and C. Folke, editors. Navigating social-ecological systems: building resilience for complexity and change. Cambridge University Press, Cambridge, UK.

Gardner, J. S., J. Sinclair, F. Berkes, and R. B. Singh. 2002. Accelerated tourism development and its impacts in Kullu-Manali, H. P., India. Tourism Recreation Research 27:9-20.

Gough, I. 2004. Human well-being and social structures: relating the universal and the local. Global Social Policy 4(3):289-311.

Gunderson, L. H., and C. S. Holling, editors. 2002. Panarchy: understanding transformations in human and natural systems. Island Press, Washington, D.C., USA.

Holling, C. S. 1973. Resilience and stability of ecological systems. Annual Review of Ecology and Systematics 4:1-23.

Hortle, K., S. Lieng, and J. Valbo-Jorgensen. 2004. An introduction to Cambodia's inland fisheries. Mekong Development Series No. 4, Mekong River Commission, Phnom Penh, Cambodia.

Human Development Report. 2002. Cambodia human development report, UNDP. Available online at: http://hdr.undp.org/statistics/data/cty/cty f KHM.html.

International Federation of the Red Cross and Red Crescent Societies. 2004. World disasters report: focus on community resilience. ATAR Roto Presse, Geneva, Switzerland.

Kirkby, J., P. O'Keefe, and C. Howorth. 2001. Introduction: rethinking environment and development in Africa and Asia. Land Degradation and Development 12:195-203.

Legerwood, J., and J. Vijghen. 2002. Decision making in Khmer villages. Pages 109-150 in J. Legerwood, editor. Cambodia emerges from the past: eight essays. Southeast Asia Publications, DeKalb, Illinois, USA.

Levin, S. A. 1999. Fragile dominion: complexity and the commons. Perseus Books, Reading, Massachussetts, USA.

Marschke, M. 2005. Livelihood in context: learning with Cambodian fishers. Dissertation. University of Manitoba, Winnipeg, Manitoba, Canada.

Marschke, M., and F. Berkes. 2005. Local level sustainability planning for livelihoods: a Cambodian experience. The International Journal of Sustainable Development and World Ecology 12:21-33.

Millennium Ecosystem Assessment (MA). 2005. Multi-scale assessments: findings of the sub-global assessments working group. Volume 4. Millennium Ecosystem Assessment. Island Press, Chicago, Illinois, USA.

Narayan, D., R. Chambers, M. K. Shah, and P. Petesch. 2000. Voices of the poor. Crying out for change. Oxford University Press for the World Bank, Oxford, UK. 
Ratner, B. 2006. Community management by decree? Lessons from Cambodia's fisheries reform. Policy review. Society and Natural Resources 19:79-86.

Reardon, T., J. Berdegue, and G. Escobar. 2001. Rural nonfarm employment and incomes in Latin America: overview and policy implications. World Development 29(3):395-409.

Redman, C., and A. Kinzig. 2003. Resilience of past landscapes: resilience theory, society longue duree. Conservation Ecology 7(1):1-14. [online] URL: http://www.consecol.org/vol7/iss 1/art14/.

Scoones, I. 1998. Sustainable rural livelihoods: a framework for analysis. Institute of Development Studies (IDS), Brighton, UK. IDS Working Paper 72.

Singh, N., and J. Gilman. 1999. Making livelihoods more sustainable. International Social Science Journal 51:539-545.

Start, D., and C. Johnson. 2004. Livelihood options? The political economy of access, opportunity and diversification. Overseas Development Institute (ODI), London, UK. ODI Working Paper 233. Available online at: http://www.odi.org.uk.

Turner, B., R. Kasperson, P. Matson, J. McCarthy, R. Corell, L. Christensen, N. Eckley, J. Kasperson, A. Luers, M. Martello, C. Polsky, A. Pulsipher, and A. Shiller. 2003. A framework for vulnerability analysis in sustainability science. Proceedings of the National Academy of Sciences 100(14):8074-8079.

Walker, B., C. S. Holling, S. Carpenter, and A. Kinzig. 2004. Resilience, adaptability and transformability in social-ecological systems. Ecology and Society 9(2):5. [online] URL: http://w ww.ecologyandsociety.org/vol9/iss2/art5/.

Wood, G. 2003. Staying secure, staying poor: the "Faustian Bargain." World Development 31 (3):455-471.

World Bank. 2004. Cambodia data profile. World Development Indicators Database. Available online at: http://www.worldbank.org. 